\title{
ESTABLISHMENT OF INDIVIDUAL CONSONANCE IN MAKASSAR MUSLIM COMMUNITIES ON CONDOMS THROUGH LOCAL FUNCTION INSTITUTION
}

\author{
Adam Badwi, Munadhir \\ Lecturers at Faculty of Public Health, \\ Universitas Pejuang Republik Indonesia (UPRI) Makassar \\ Jalan Gunung Bawakaraeng No.72, Lariang Bangi, Makassar, \\ Kota Makassar, Sulawesi Selatan 90151 \\ Email: ab.adamskm@gmail.com; munadhir.ado@gmail.com
}

\begin{abstract}
This study aims to analyze the factors that influence the occurrence of individual cognitive dissonance in the community towards condoms in the city of Makassar through a quantitative approach to analytical design. The location of the study was in Makassar City on the grounds that Makassar City had the largest HIV and AIDS cases in South Sulawesi, the level of condom use was still very low, the HIV / AIDS epidemic rate was very high in the last 3 years, especially in the pattern of HIV and AIDS transmission through sex heterosexual. The results found that religious norms, cultural values and experience of condom use have an influence on the occurrence of individual cognitive dissonance towards the condom and experience of condom use is the most dominant factor affecting the occurrence of individual cognitive dissonance in the condom.
\end{abstract}

Keywords: Cognitive dissonance, religious norms, cultural values, experience of condom use. 


\section{Introduction}

The existence of condoms in the middle of the community is in an unsanctioned institution (Gillin dan Gillin dalam Soekanto, 1990) namely social institutions that are rejected by society, even though their existence cannot be avoided. This has an impact on the duality of knowledge, attitudes, perceptions and actions of the community towards condoms which can be seen clearly in the social interaction of the community. The duality of knowledge, attitudes, perceptions and actions is an indication of the individual's cognitive dissonance in the community towards condoms

The symptom of the duality of knowledge about condoms can be seen in social interactions in the community, one form of which is the occurrence of individual denial of the effectiveness of condoms has even become a separate debate and leads to annual ritual debate. This can be shown by one of them revealed by Hawari (2012) in his book: HIV / AIDS Global Effect in the Psychological Dimension that condoms are not effective in preventing HIV and AIDS because the pore diameter of a condom is much larger than the HIV virus.

The denial carried out is a diversion of science to the scientific truth of laboratory tests on the effectiveness of condoms as stated by the community who believe in the effectiveness of condoms which are characterized by a high sense of trust that condoms are classified as health products under the Indonesian Ministry of Health. Believing communities also believe that as a health product, condoms 
are an effective health tool in efforts to prevent and control HIV and AIDS. In addition, for people who believe in the effectiveness of condoms, they assume that denial of the effectiveness of condoms Some people have violated one of the main points of the national AIDS prevention strategy which states that everyone has the right to get the right information to protect themselves and others against HIV and AIDS infection. The effectiveness of condoms is reinforced by the results of a 2015 National Family Planning Association (PKBI) study which stated that the quality of condoms currently circulating, namely latex condoms is a condom that is quite strong and has been tested for laboratory feasibility standards to hold sperm and HIV. In line with this, the effectiveness of condoms in preventing HIV and AIDS has been proven by the results of a study conducted by Isabelle de Vincenzi in 1994 which was published in the New England Journal of Medicine on 11 August 1994 that reported two years of research on 245 discordant couples (from each pair is one of them HIV +). The result, in 124 couples who consistently used condoms in each sex relationship, found no HIV transmission. In 121 other couples who were inconsistent using condoms found HIV transmission in 12 people.

Individual cognitive dissonance in society occurs because of the incompatibility between people's attitudes and behavior towards condoms because of the strong understanding of community knowledge and thinking patterns that place rationality on prior knowledge where 
condoms and their use are one of the health tools used in pregnancy prevention in The family planning program is not a means of preventing HIV and AIDS, which is still considered a disease that only exists in the community that does not maintain values, moral and religious principles so it is not appropriate to be widely disseminated to the community. The condition of individual cognitive dissonance in society that occurs when it is not resolved will trigger behavior that will actually harm the community and its health, especially in the transmission of HIV and AIDS which is increasingly out of control.

Efforts to prevent and control HIV and AIDS in Makassar City through increasing condom use in groups at risk of experiencing various barriers mainly due to the occurrence of cognitive dissonance of individuals in society that have an impact on the increasing cases of HIV and AIDS. This can be seen in the HIV and AIDS data of the South Sulawesi Provincial Health Office in 2015 which shows that the number of new cases of HIV and AIDS in the last 3 years has increased significantly, namely in 2013 as many as 1,148 new cases increased by 1,285 new cases in 2014 and as many as 1,322 new cases in 2015. Meanwhile in the average data the attack rate has increased from 2013 compared to 2014 as much as $17.3 \%$ and has decreased the average rate of attack (attack rate) from 2014 compared to the year 2015 as many as $15.3 \%$. In other data, namely data from the behavior change survey in Indonesia carried out by the Indonesian Ministry of Health in 2014, 55\% of all new HIV and AIDS infections in 
Indonesia were caused by heterosexual sex (RI Ministry of Health, 2014) and based on condom use survey results in Makassar City conducted by the Mitra Husada Foundation $(\mathrm{YMH})$ in 2015, the rate of condom use in risky sex is still very low, namely $50 \%-60 \%$. Meanwhile, it is believed that if the rate of condom use reaches $100 \%$ it will have a significant influence in holding back the rate of HIV and AIDS epidemic in Makassar City.

Based on the results of preliminary research that has been done before, the individual's cognitive dissonance in the condom is characterized by the occurrence of duality of knowledge, attitude duality, perceptual duality, hypocritical action and self-efficacy caused by several factors including religious norms, cultural values and condom use experiences. So that an in-depth analysis of the influence of religious norms, cultural values and experience of condom use is needed and factors that predominantly influence the cognitive dissonance of individuals in the condom.

\section{Research Method}

This research was conducted with a quantitative analytical design approach to analyze factors that influence the occurrence of individual cognitive dissonance in the community towards condoms in Makassar City. The population in this study were people in the city of Makassar. The sampling method in this study is to use a multistage sampling technique. Sampling uses more than one probability sampling technique. For the first stage using the stratified 
sampling method then the simple random sampling method in the second stage and so on until it reaches the desired sample. Stratified random sampling, which is a technique used when the population has non-homogeneous members and proportional strata, for example in the number of family heads $(K K)$ in Makassar City. The number of sample determination is to make a sample withdrawal by entering the number of households from the entire population in Makassar City then selecting several households per subdistrict to be sampled in the study.

The sample size is calculated by the Slovin formula (Sevilla, 1993):

$\mathrm{n}=\mathrm{N} /(1+\mathrm{N}(\mathrm{e}) 2)$

Information:

$\mathrm{n}=$ sample size

$\mathrm{N}=$ population size $(\mathrm{KK})$

$\mathrm{e}=$ desired degree of accuracy $=0.05$.

Based on the formula above, then from 358,054 households in Makassar City (Makassar City BPS in 2017), the number of samples is as follows:

$$
\begin{gathered}
n=\frac{(358.054)}{1+358.054(0.05)^{2}} \\
n=\frac{358.054}{896}=400 \text { samples } \\
\mathrm{n}=400 \text { samples }
\end{gathered}
$$


The number of each class is calculated using the proportional stratified random sampling formula.

$\mathrm{n} \_\mathrm{i}=\mathrm{Ni} / \mathrm{N} \mathrm{n}$

Information:

$\mathrm{n} \_\mathrm{i}=$ sample size of households per sub-district

$\mathrm{N} \_\mathrm{i}=$ population of $\mathrm{KK}$ per sub-district

$\mathrm{n}=$ sample size

$\mathrm{N}=$ population size

Data analysis used in this study is statistical analysis with logistic regression test using computer programs.

\section{Findings and Discussion}

1. Religious norms against individual cognitive dissonance of condoms.

In the view of sociology, religion is one aspect of social life and part of the social system of a society besides other elements. Religion is a view of life that must be applied in the lives of individuals or groups. Both have a relationship of mutual influence and are interdependent with all the factors that contribute to forming social structures in any society. Viewed from the point of view of the category of human understanding, religion has two aspects that distinguish it in its manifestation, namely as follows: First, psychological aspects, namely a subjective condition or condition in the human soul, with regard to what is felt by adherents of religion. This condition is commonly called a religious condition, which is a condition of being obedient 
and obedient to those who are worshiped. Second, the objective aspect, namely the external aspect which is also called objective event, the empirical dimension of religion. This situation arises when religion is expressed by its adherents in various expressions, both theological, ritual and fellowship expressions (Kahmad, 2002: 14-15).

The concept of religion according to sociology is an empirical definition. Sociology has never provided an evaluative definition of religion, sociology is only able to provide a descriptive definition (describing what it is), which reveals what the adherents understand and experience (Boty, 2015: 42). The problem of religion cannot possibly be separated from people's lives, because religion itself turns out to be needed in community life.

Ishomuddin (2002: 54) describes, in practice the function of religion in society includes:

a. Educational Function

The adherents of religion believe that the teachings of the religion they profess provide teachings that must be obeyed. Jurisprudence of religion functions to order and prohibit. Both of these elements have a background directing guidance so that the individual adherents become good and get used to the good according to the teachings of each religion.

b. Rescue Function

Wherever a man is he always wants himself safe. The security taught by religion is a wide-ranging security. The security provided by religion to its followers is the 
salvation of the two worlds and the hereafter. In achieving salvation the religion teaches its followers through: the introduction of a sacred problem of faith to God.

c. Function as Atonement

Through the religion of a guilty person / sin can achieve inner peace through the guidance of religion. Sense of guilt and guilt will soon be lost from the inner one if a transgressor has redeemed his sin through repentance, cleansing or redemption.

d. Function As Social Control

Religious teachings by adherents are considered norms, so in this case religion can serve as social supervision individually and as a group because: first, religion by institution, is the norm for his followers, secondly, dogmatically (teaching) religion has a profoundly critical function ( revelation, prophecy).

e. Function of Solidarity Taste

Psychologists who are equal believers of religion will feel equally and single; faith and trust. This sense of unity will build a sense of solidarity both in groups and individuals, and sometimes can build a solid sense of brotherhood.

f. Transformative Function

The teachings of religion can change the life of one's personality / group into a new life in accordance with the teachings of the religion it adheres to. The new life he received based on the religious teachings he 
embraced was sometimes able to change his loyalty to the customs or norms of life that he had adopted before.

g. Creative Function

Religious teachings encourage and encourage followers to work productively not only for their own interests but also for the benefit of others. Religious adherents are not only told to work routinely in the same lifestyle, but are also required to innovate and discover new things.

h. Sublimative function

The teachings of religion sanctify all human endeavors, not only those that are ukhrowi religions, but also worldly ones. All human endeavors as long as they do not conflict with religious norms if done on sincere intentions, because for God is worship.

Individuals who declare their rejection of condoms are influenced by one of the factors, namely religion. The use of condoms is contrary to the religion that is believed by individuals. Some literature on the use of condoms in the view of Islam which shows the division of views is a conservative view which states that the use of condoms is unlawful and a moderate view that states that condoms are used with the law makruh.

Both of these views each have their own reasons, namely the existence of a hadith narrated by Muslims (1442), which reads: "that the Prophet Muhammad SAW was once asked about 'azl, then he said," That (' azl) is actually a hidden 
burial "As for 'azl or in medicine called Discontinuous Senggama (Coitus Interuptus) which is a romance in which ejaculation is carried out outside, a kind of natural contraception method. Referring to the hadith, live burial is murder and the murder law is clearly forbidden. Condom use allowing 'azl not to occur, but still making the cells in the sperm die. Both are different, but because the effect is the same, they are equalized (Tribun-Medan.com, accessed on April 10, 2017).

Positioning condom use which is contested by some individuals which prohibits condom use and some other individuals allow especially on the basis of knowledge sourced from scholars who are believed by the individual to make the existence and use of condoms a problem that will continue to be contested without finding an agreement as a solution. The existence and use of condoms will continue to be discussed in the process of interaction between individuals, between groups and between communities with conflicts that experience deadlock without a solution as a certainty. This makes the existence and use of condoms will be discussed in a quiet social practice, not resonating and will not be festive.

Meanwhile on the different side, some individuals have the view that condom use does not conflict with the religion that is believed by individuals. The existence of condoms is seen as a medical device that is placed in parallel with other medical devices that are used for health purposes. Some individuals in the process of interaction with other individuals in their social communities have the view that the 
existence of condoms does not need to be associated with religious aspects because of the position of condoms as medical devices that are used as a vehicle for population control and prevention of HIV and AIDS. Individuals who hold this view are in reality mostly involved in group health care groups in general and specifically in the field of HIV and AIDS prevention.

In the dimensions of the practice of condom use which has a contraceptive perspective, it also experiences dissonant views for some individuals. The use of condoms is said to be one of the efforts to inhibit population growth for the community but the practice of using contraception in community life in one section is well received but in other parts it is considered not in accordance with the conservative religious norms believed.

So that the existence and use of condoms in the midst of society always raises a view that leads to the occurrence of cognitive dissonance where the existence and use of condoms can be accepted and simultaneously rejected at the same time. This starts from the occurrence of individual cognitive dissonance in individual practice, continuing to individual cognitive dissonance in group practice and ending in individual cognitive dissonance in the practice of society.

The practice of individuals who experience cognitive dissonance, based on the results of research conducted, the level of tendency of individuals who experience cognitive dissonance which is dominantly influenced by religious norms that are conservative. Nevertheless, in general it can be 
concluded that most individuals understand religious norms with moderate views so that the existence and use of condoms in the influence of religious norms will experience a shift in acceptance so that efforts made in the framework of condoms as medical devices can reduce the occurrence of individual cognitive dissonance in various social practice in the middle of society.

This is in line with various literatures that show condom use is permissible in Islam based on the opinions of some scholars who claim that condom use with Al Azl's law as stated by Jabir radhiallahu anhu which states that we (the companions) did Azl in the time of the Prophet Shallallaahu 'alaihi wa sallam "(HR. Bukhari no. 5207 / 5208-5209, Muslim no. 1440). In other narrations in Musnad Abi Ya'laa stated that we did Azl in the time of the Prophet sallallaahu' alaihi wa sallam, and he did not banned us from him (Sahih Muslim no. 1440, Musnad Abi Ya'laa No. 2255) (http://www.muslimah.co.id/fiqih/2016/02/25 accessed on April 10, 2017).

However, some views suggest that the use of condoms is a prohibited act having a footing based on the contemporary jurisdiction that in the days of Prophet Muhammad SAW had never been discussed about the condom but it was attributed to Azl that is producing sperm water outside as contained in the narrated hadith by Buhari in Fathul-Bariy 9/305 Assyamillah book by Ibn Hajar Al Asqanily who discussed that $\mathrm{Al} \mathrm{Azl} \mathrm{is} \mathrm{depriving} \mathrm{(penis)} \mathrm{after}$ the penetration of agar (semen) spilled out farji 
(http://www.muslimah.co.id/fiqih / 2016/02/25 accessed on April 10, 2017). In line with that, Imam Nawawi said that Azl is a person who performs a torpedo (intercourse) which when his tears will be spilled then he expels (his cock) then sheds it outside his genitals (wives). (http://www.muslimah.co.id/fiqih/2016/02/25 accessed on April 10, 2017).

2. Cultural values of individual cognitive dissonance towards condoms

Culture is one factor that causes individual cognitive dissonance to condoms. Cultural values are values that exist and develop in society. For Koentjoroningrat (1984: 8), cultural value is the first level of ideal or customary culture. Cultural value is something that is considered very influential and used as a guide for a community in determining its attitudes, thoughts and actions. Koentjoroningrat (1984: 8)

In addition, this cultural value has a system of cultural values which consists of a conception that lives in the minds of most people about things that they must consider very valuable in their lives. So that this cultural value system serves as the highest guideline for the behavior of individuals, families, groups and society. Concretely this cultural value system is manifested in the form of special rules relating to cultural and legal values.

Cultural values are agreed upon values and embedded in a society in the form of habits, beliefs, symbols that are used as a reference for behavior and responses to what will 
happen or is happening. Cognition that someone has in a culture may be different cognition with other cultures.

In general, the people of South Sulawesi Province consist of 4 large ethnic groups, namely ethnic Bugis, Makassar, Mandar and Toraja who have their own cultural values. In particular, Makassar City as the capital of South Sulawesi Province has also settled and spread the four major ethnic groups, although the community still places the Makassar ethnic as an indigenous ethnic group in Makassar City.

Makassar ethnic with Makassar cultural values, have a philosophy of life that must be upheld including siri na pacce culture which by some people are still loyal to guard and by others have been degraded due to the rapid progress of information, technology and consumerism so that the influx of foreign cultures cannot be stopped .

For people who hold fast to the philosophy of siri na pacce, it is counterproductive in its application, especially to prevent the spread of HIV and AIDS prevention because the community places this siri philosophy only in situations where governments, non-governmental organizations and other health organizations are trying to prevent HIV and AIDS such as counseling, socialization or prevention campaigns for HIV and AIDS which actually inhibit these efforts because the public views that talk of condom use and risky sex is seen as a violation of the boundaries of the siri region on the grounds that the community still has siri and does not want their personal territory to be violated by people other. 
Meanwhile, social reality shows that the HIV and AIDS epidemic has continued to increase lately in South Sulawesi, especially in Makassar City.

Based on the results of the study, it was shown that some individuals stated that if there were community members infected with HIV and AIDS, it would be seen as a disgrace in society. The strong cultural norms internalized in individuals in Bugis and Makassar society reinforces that there are penalties waiting for individuals who carry out cultural extractions such as contracting HIV and AIDS which is a disgrace. However, the implementation of cultural norms which are still concentrated on the impacts caused while efforts in the form of processes do not get enough attention. In this process, there is a clash of cultural norms because at the level of the process of risky sex and condom use do not want to be discussed openly while at this point some of the impacts that will occur can be minimized.

On the dimensions of condom use as a medical device in family planning for some individuals, the use must be rejected because using condoms means violating cultural teachings inherited by parents who have principles in family culture that are many children with lots of luck. This is reinforced by various studies that suggest that one of the obstacles in the implementation of family planning in Indonesia is that there are still cultural norms that are maintained as ancestral heritage among many children, many sustenance and the view that each child born in the world has brought his sustenance. 
Based on the findings of this study it can be described a pattern of dissonant existence and use of condoms where the positioning of condoms is simultaneously in the individual, namely acceptance and rejection caused by the existence of cultural norms which are still preserved and providing space for government-run programs

This is in line with the statement of the Chairperson of the Indonesian Midwives Association (IBI) Chairperson in 2014 (quoted in health.detik.com, accessed on April 10, 2017) that the culture of many children is a lot of sustenance that cannot be released in most Indonesian people. The existence of such a strong culture in Indonesian society is one of the biggest obstacles to family planning programs.

3. Experience the use of condoms for individual cognitive dissonance in the community towards condoms.

Cognition that is not consistent with the experience that has been passed will give rise to dissonance. Experience as an event that was truly experienced before this time. Experience is one of the results obtained by humans from interactions with their environment.

This experience contains a variety of things that can be known including knowing more about a person's understanding of condoms. Experience is born of the human sensing process in the environment. This experience then becomes a human benchmark in carrying out activities or responding to things in the future. The experience of one's past is like a literature book that contains all kinds of 
information needed to be used as a foundation for humans to take attitudes and decisions in every segment of their lives. Past experience is an event that was truly experienced in the period before now which includes things that have been learned, known and received in the past.

The experience of condom use for some individuals has a significant contribution in the occurrence of individual cognitive dissonance in society. This can be seen in the building of the views of individuals who actually experience an increase in their cognitive dissonance levels after the experience of having used condoms but in their use provides a negative assessment of condom use in the form of inconvenience in the form of not feeling pleasure in sexual relations. This gave rise to a new decision where the individual did not wish to return to using a condom. Meanwhile, the expression of experience after decision-making using condoms is expected to be more expressive and enthusiastic but in reality there is the opposite.

The results of this study can be illustrated from the experience gained in the use of condoms for some other individuals stating that sexual intercourse felt by using a condom is quite good but will feel better when having sexual intercourse without using a barrier. The experience of condom use in various individual practices is expected to be an intermediary medium for other individuals who still doubt the feelings obtained so that they can trigger individuals who have not used condoms because of their doubts to turn to the decision to use condoms. However, an inverse reality is 
obtained which is the result of an individual experience that has used a condom but gives a negative assessment that will affect other individuals so that the view for the condom goes in place.

Some other individuals with experience in using condoms share experiences that are felt when using a condom are associated with a very dirty feeling in condom use, especially after sexual intercourse where sperm is left in a condom that must be cleaned, condoms must be rolled up, condoms must be folded and finally the condom must be disposed of in a place that again causes individual confusion.

Finally, various summaries of experiences related to discomfort in condom use raise rejection decisions in the context of use for individuals despite being permissive if there is a socialization of condom use in the community. So that in various socialization and counseling activities to the community related to condom use, people are still visited by many people, but in matters of personal use, it remains a personal choice for each individual. It can be illustrated that the excitement and the number of participants present in various activities on the dissemination of condom use is not a benchmark of the problems of the effectiveness of condom use in efforts to prevent disease and population control efforts.

\section{Concluding Remarks}

Based on the results of the research conducted, it was concluded that religious norms, cultural values and the 
control of condom use had an influence on the occurrence of individual cognitive dissonance in the condom and experience of condom use was the most dominant factor affecting the individual's cognitive dissonance towards condoms.

\section{Bibliography}

BPS Kota Makassar, 2017, Makassar dalam Angka 2017, Makassar

Boty, Middya, 2015, Agama dan Perubahan Sosial, Artikel Jurnal Islam No.15/Th.XIV, Juni 2015

Dinas Kesehatan Provinsi Sulawesi Selatan, 2015, Situasi HIV dan AIDS di Provinsi Sulawesi Selatan, Makassar, Dinas Kesehatan Provinsi Sulawesi Selatan

Hawari, D, 2012, Global Effect HIV/AIDS Dimensi Psikoreligi, Jakarta, Badan Penerbit Fakultas Kedokteran Universitas Indonesia

Ishomuddin, 2002, Pengantar Sosiologi Agama, Jakarta, Ghalia Indonesia

Kahmad, Dadang, 2002, Sosiologi Agama, Bandung, PT. Remaja Rosda Karya

Kementerian Kesehatan RI, 2014, Survey Perubahan Perilaku di Indonesia, Jakarta, Kementerian Kesehatan RI

Koentjaraningrat, 1984, Kebudayaan Jawa, Jakarta, Balai Pustaka 
Perkumpulan Keluarga Berencana Indonesia, 2015, Data dan Informasi Perkumpulan Keluarga Berencana Indonesia (PKBI) Tabun 2015, Jakarta, Perkumpulan Keluarga Berencana Indonesia

Sevilla, C, et, Al. 1993. Pengantar Metode Penelitian, Jakarta, Universitas Indonesia Press

Soekanto, S, 1990, Sosiologi Suatu Pengantar, Jakarta, Rajawali

Vincenzi, I.D, 1994, A Longitudinal Study Of Human Immunodeficiency Virus Transmission By Heterosexual Partners, New England Journal of Medicine

Yayasan Mitra Husada, 2015, Survey Penggunaan Kondom di Kota Makassar Tahun 2014, Makassar, YMH 